\title{
PARA ALÉM DAS FRONTEIRAS: CIDADANIA TRANSNACIONAL
}

\section{PARA ALLÁ DE LAS FRONTERAS: CIUDADANÍA TRANSNACIONAL}

\author{
Elaine Dupas ${ }^{1}$ \\ Leonardo Chaves de Carvalho ${ }^{2}$ \\ Luciani Coimbra de Carvalho ${ }^{3}$
}

\begin{abstract}
RESUMO: A intensificaçâo e o aumento dos deslocamentos humanos além das fronteiras nacionais compeliu os Estados a lidar com a necessidade do acolhimento e da integraçâo dos indivíduos que cruzam as fronteiras. No contexto da transnacionalidade, a possibilidade de concessâo do status de cidadâo a estes indivíduos transnacionais ganha papel de destaque nas questóes atuais que merecem ser debatidas por toda a comunidade internacional, uma vez que a cidadania e a proteçăo dos direitos humanos possuem pontos de convergência. Este artigo é parte da dissertaçấo de mestrado intitulada "Cidadania transnacional: para além da nacionalidade" desenvolvida na Universidade Federal de Mato Grosso do Sul (2018) e demonstra que a cidadania transnacional é uma realidade presente na comunidade internacional contemporânea e que tal fato social vai além das fronteiras. Sáo apresentadas categorias de direitos que deveriam ser garantidas a todos os indivíduos para ser considerados "cidadâos plenos". Ademais, é feita a dissociaçâo dos conceitos de cidadania e nacionalidade. É utilizado o Estatuto da Cidadania do Mercosul para demonstrar que açōes estăo sendo efetivadas em busca da cidadania transnacional. Trata-se de pesquisa qualitativa, de cunho exploratório, pautada em análise bibliográfica.
\end{abstract}

PALAVRAS-CHAVE: Deslocamentos humanos. Transnacionalidade. Cidadania. Cidadâo transnacional. Direitos Humanos.

RESUMEN: La intensificación y el aumento de los desplazamientos humanos más allá de las fronteras nacionales ha obligado a los Estados a hacer frente a la necesidad de la acogida y la integración de las personas que cruzan las fronteras. En el contexto de la transnacionalidad, la posibilidad de conceder el status de ciudadano a estos individuos transnacionales gana un papel destacado en las cuestiones actuales que merecen ser debatidas por toda la comunidad internacional, una vez que la ciudadanía

1 Doutorando em Direito do Estado no Dinter na Universidade Estadual de Săo Paulo (USP) e Universidade Federal de Mato Grosso do Sul (UFMS). Mestra em Fronteiras e Direitos Humanos pela Universidade Federal da Grande Dourados (UFGD). Bacharel em Direito pela Universidade Federal de Mato Grosso do Sul (UFMS). Graduanda em Ciências Sociais na UFMS. Advogada. elaine.dupas@gmail.com

2 Mestre em Direito pela Faculdade de Direito da Universidade Federal de Mato Grosso do Sul (FADIR/ UFMS).Bacharel em Direito pela FADIR/UFMS. Servidor técnico-administrativo da UFMS/Câmpus de Paranaíba.leonardo.chaves@ufms.br

3 Professora Adjunta da Universidade Federal de Mato Grosso do Sul no curso de graduaçáo e no mestrado em Direito. Mestre e Doutora em Direito do Estado pela PUC/SP. lucianicoimbra@hotmail.com 
y la protección de los derechos humanos poseen puntos de convergencia. Este artículo es parte de la disertación de maestría titulada "Ciudadanía transnacional: más allá de la nacionalidad" desarrollada en la Universidad Federal de Mato Grosso do Sul (2018) y demuestra que la ciudadanía transnacional es una realidad presente en la comunidad internacional contemporánea y que tal hecho social va además de las fronteras. Se presentan categorías de derechos que deberían garantizarse a todos los individuos para ser considerados "ciudadanos plenos". Además, se hace la disociación de los conceptos de ciudadanía y nacionalidad. Se utiliza el Estatuto de la Ciudadanía del Mercosur para demostrar qué acciones se están realizando en busca de la ciudadanía transnacional. La investigación es bibliográfica, con final exploratorio y descriptivo, hecha bajo el método deductivo.

Palavras clave: Desplazamientos humanos. Transnacionalidad. Ciudadanía. Ciudadano transnacional. Derechos humanos.

\section{INTRODUÇÃO}

A cidadania transnacional é a cidadania que nâo observa fronteiras e Estados específicos. É a cidadania que se baseia nos direitos humanos e na garantia de proteçâo da dignidade humana, năo importando qual território o indivíduo escolheu para viver. É a cidadania que năo vê critérios sanguíneos ou geográficos, mas sim humanos. É a cidadania dissociada da nacionalidade. É a cidadania que o Estado deve conceder ao indivíduo quando este adentra em seu território, cidadania esta conexa a direitos básicos, como civis, sociais, econômicos e culturais.

O Estado era o único protagonista das relaçôes que se davam além das fronteiras. Porém, devido à mitigaçăo da soberania estatal absolutista, a interdependência dos Estados por conta do processo globalizatório e a internacionalizaçâo dos direitos humanos, foram elevados à categoria de sujeitos de direitos internacionalmente: as organizaçôes internacionais e o indivíduo.

O indivíduo transnacional que se desloca entre as fronteiras dos Estados agora é reconhecidamente um sujeito de direito internacional, amparado por um arcabouço jurídico internacional e regional de proteçâo dos direitos humanos, resultante de um processo de internacionalizaçáo destes direitos, como, a Lei de Migraçáo, lei n. 13.445, de 24 de maio de 2017. Como consequência deste novo enquadramento do indivíduo na comunidade global, a cidadania e os direitos humanos săo temas que merecem ser colocados em destaque na seara jurídica e acadêmica, afinal os Estados devem estar preparados para receber e integrar socialmente o indivíduo transnacional.

O fenômeno internacional de deslocamento humano reflete a realidade do momento vivido pela comunidade de países. Como tal realidade náo é estática, as características dos fluxos destes deslocamentos também se alteram com o decorrer do tempo. Houve momentos nos quais o indivíduo que se deslocava se via obrigado a se integrar forçadamente na sociedade estrangeira escolhida para viver e ter um recomeço, pois o contato com sua naçăo de origem se rompia quase totalmente por diversos motivos. Atualmente, é possível que o indivíduo mantenha relaçōes com ambas as sociedades: a do país estrangeiro para o qual se deslocou e a do seu país natal. 
Esta realidade foi alterada tendo em vista vários fatores que contribuíram para se ter uma comunidade de Estados mais estreita, interdependente e cooperativa. Os principais fatores contribuintes para esta nova realidade foram a globalizaçấo, a internacionalizaçăo dos direitos humanos e a transnacionalidade. Utilizamos a concepçăo de Milton Santos para compreender o fenômeno que possibilite a construçăo de uma globalizaçăo mais humana e que permite "a enorme mistura de povos, raças, culturas, gostos, em todos os continentes" (SANTOS, 2000, p. 10).

O presente artigo tem por objetivo a análise da questāo da cidadania dos indivíduos que fazem parte do fluxo do deslocamento humano internacional. Tal análise será feita no contexto atual da transnacionalidade, buscando verificar a possibilidade de uma cidadania transnacional na sociedade internacional contemporânea.

O objetivo é demonstrar ser possível uma concepçăo da cidadania transnacional no cenário internacional contemporâneo. Para isto, o conceito clássico de cidadania é tomado como base para se debater a necessidade de sua atualizaçáo e ampliaçấo devido à conjuntura dos direitos humanos.

Săo apresentadas as categorias de direitos que deveriam ser garantidas a todos os cidadâos: direitos civis, políticos, sociais, econômicos e culturais. Levanta-se o questionamento a respeito da necessidade ou năo de um indivíduo ser titular destes direitos para, assim, ser considerado um cidadăo pleno. Enfatiza-se uma breve discussăo a respeito dos direitos políticos do indivíduo transnacional.

É proposta a desconstruçâo do conceito clássico de cidadania ao dissociá-lo do conceito de nacionalidade, sob a argumentaçâo de que a verticalizaçấo entre Estado e cidadâo já năo seria restritiva às questôes sanguíneas ou geográficas devido ao arcabouço jurídico internacional e regional de proteçăo dos direitos humanos, além da transnacionalidade presente na comunidade internacional.

\section{A POSSIBILIDADE DE CIDADANIA TRANSNACIONAL: PARA ALÉM DAS DIVERSAS FRONTEIRAS}

Para dar início a análise proposta, faz-se necessário discutir a atualizaçâo e ampliaçấo do conceito clássico de cidadania, tendo como base a proteçăo dos direitos humanos do indivíduo. Para isto, importante que haja a dissociaçăo dos conceitos de nacionalidade e cidadania, uma vez que a ideia de verticalizaçấo entre Estado e cidadăo já náo é restritiva como no passado, devido ao arcabouço jurídico internacional e regional de proteçăo dos direitos humanos, além da transnacionalidade presente nesta comunidade internacional.

Fronteira, além de física, é espaço de diferenciaçăo entre territórios, políticas e culturas. Logo, ser cidadáo transnacional e ter todas as vertentes respeitadas pelas naçôes.

Diante deste quadro, busca-se demonstrar a possibilidade jurídica da concepçăo de cidadania transnacional no cenário internacional atual, utilizando, principalmente, como marco jurídico a cidadania do estrangeiro no Brasil com fulcro na análise da Lei n. ${ }^{\circ}$ 6.815/1980 (Estatuto do Estrangeiro) e da nova Lei de Migraçấo brasileira (Lei n. ${ }^{\circ}$ 13.445/2017). 


\subsection{CIDADANIA: CONCEITO EM EVOLUÇÃO}

Para conceituar o termo cidadania da maneira mais clássica conhecida, parte-se da nacionalidade, que é a "ligaçăo juridicamente estabelecida entre um indivíduo e determinado Estado" (TAVARES, 2008, p. 724).

A Declaraçăo Universal dos Direitos Humanos de 1948 prevê a nacionalidade como um direito humano em seu artigo XV, ao estabelecer que "todo homem tem direito a uma nacionalidade" e que, "ninguém será arbitrariamente privado de sua nacionalidade, nem do direito de mudar de nacionalidade".

Este pertencimento a um Estado por meio da nacionalidade é comumente associado quando se busca o conceito de cidadania. O ideal clássico de cidadania remete à concepçâo de cidadăo pertencente a um determinado Estado com direitos e deveres a serem observados por este ente estatal.

Benevides (1994), ao escrever sobre cidadania e democracia, explica essa relaçáo entre nacionalidade e cidadâo com base na teoria constitucional moderna, que expóe a existência de um vínculo jurídico entre o indivíduo (cidadăo) e o Estado. Este cidadâo seria "o portador de direitos e deveres fixados por uma determinada estrutura legal (Constituiçấo, leis) que lhe confere, ainda, a nacionalidade". O autor ainda acrescenta que "cidadăos săo, em tese, livres e iguais perante a lei, porém súditos do Estado. Nos regimes democráticos, entende-se que os cidadăos participaram ou aceitaram o pacto fundante da naçăo ou de uma nova ordem jurídica" (BENEVIDES, 1994, p.7).

Entretanto, nacionalidade e cidadania săo conceitos distintos. André Ramos Tavares (2008, p. 726) os diferencia escrevendo que "cidadăo é o indivíduo que reúne as condiçōes necessárias para ter e exercer os chamados direitos políticos. Pressuposto básico do cidadăo é o de que seja nacional do respectivo Estado. Mas nem todo nacional possui a qualidade de cidadăo". Desta forma, conclui o autor que "o conceito de cidadăo é mais restrito que o de nacional, que, por seu turno, como visto, é mais restrito que o de integrante da populaçăo de um país".

Como se depreende das palavras de Tavares, ser cidadăo é ter direitos políticos (tendo os direitos civis consequentemente atrelados). A cidadania estaria ligada ao direito de votar e ser votado. Exercer o voto seria exercer a cidadania. No entanto, esta conceituaçăo restritiva nâo condiz com a evoluçăo histórica da cidadania.

Ao longo da história dos estudos sobre cidadania, é comum desdobrá-la sob a perspectiva de três esferas de direitos: os civis, os políticos e os sociais. Portanto, para ser considerado um cidadáo de modo pleno, a titularidade destes três direitos, ao mesmo tempo, seria um pressuposto necessário.

José Murilo de Carvalho, em sua obra "Cidadania no Brasil - o longo caminho", explica cada um destes direitos de modo detalhado, os quais, juntos, dariam a condiçăo plena de cidadāo a um indivíduo.

Sucintamente, os direitos civis sâo "os direitos fundamentais à vida, à liberdade, à propriedade, à igualdade perante a lei"; os direitos políticos se referem "à participaçâo do cidadâo no governo da sociedade"; e, por fim, os direitos civis "garantem a participaçăo na riqueza coletiva", pois "incluem o direito à educaçăo, ao trabalho, ao salário justo, à saúde, à aposentadoria" (CARVALHO, 2008, p. 9-10). 
Importante registrar que o modo como estes direitos săo conquistados por uma sociedade durante a sua história influencia na visâo que esta sociedade possui de cidadania. Os ensinamentos do sociólogo britânico Thomas Humprey Marshall, quanto à ordem de surgimento dos direitos civis, políticos e sociais em uma sociedade sâo amplamente citados como paradigma.

Os estudos de T. Marshall têm como referência o processo de conquista da cidadania na Gră-Bretanha. Segundo o sociólogo, os direitos civis foram os primeiros reivindicados e conquistados pela sociedade britânica, seguidos pelos direitos políticos e, finalmente, pelos direitos sociais, já no Estado de Bem-estar britânico:

Até o momento, meu objetivo se resumiu em traçar, de modo resumido, o desenvolvimento da cidadania na Inglaterra até o fim do século XIX. Com esta finalidade, dividi a cidadania em três elementos: civil, político e social. Tentei demonstrar que os direitos civis surgiram em primeiro lugar e se estabeleceram de modo um tanto semelhante à forma moderna que assumiram antes da entrada em vigor da primeira Lei de Reforma, em 1832. Os direitos políticos se seguiram aos civis, e a ampliaçáo deles foi uma das principais características do século XIX, embora o princípio da cidadania política universal năo tenha sido reconhecido senăo em 1918. Os direitos sociais, por outro lado, quase que desapareceram no século XVIII e princípio do XIX. O ressurgimento destes começou com o desenvolvimento da educaçăo primária pública, mas náo foi senăo no século XX que eles atingiram um plano de igualdade com os outros dois elementos da cidadania (MARSHALL, 1967, p. 75).

É possível encontrar situaçôes em que um indivíduo possui uma das três categorias dos direitos relacionados à cidadania, porém, năo outras. Pode ocorrer de existir a efetivaçăo de direitos civis sem os direitos políticos. Nesta situaçâo, Carvalho (2008, p.10) escreve que "sem os direitos civis, sobretudo a liberdade de opiniăo e organizaçăo, os direitos políticos, sobretudo o voto, podem existir formalmente mas ficam esvaziados de conteúdo e servem antes para justificar governos do que para representar cidadăo".

Outra possibilidade é de que a pessoa tenha direitos sociais, mas nâo os civis e políticos. Carvalho (2008) também explica que os direitos sociais, em tese, "podem existir sem os direitos civis e certamente sem os direitos políticos. Podem mesmo ser usados em substituiçăo aos direitos políticos. Mas, na ausência de direitos civis e políticos, seu conteúdo e alcance tendem a ser arbitrários" (CARVALHO, 2008, p. 10).

Situaçôes como estas podem ser frequentemente encontradas quando se analisam as condiçôes dos transnacionais, os quais, na maioria das vezes, năo săo considerados cidadâos de um determinado Estado. Porém, os pactos internacionais e alguns dispositivos legais internos relacionados aos direitos humanos garantem uma ou mais das três categorias de direitos relacionadas à cidadania aqui apresentadas.

Quando se analisa estas categorias de direito sob a ótica da cidadania transnacional, a questáo que paira é sobre a titularidade e o exercício dos direitos políticos, afinal, esta categoria de direitos é a única que, na maioria das vezes, nâo é concedida a um transnacional em um território estrangeiro.

Assim, se um indivíduo transnacional possuir direitos civis e sociais, porém năo possuir direitos políticos, mesmo assim ele poderia ser considerado um cidadáo? Haveria neste caso a cidadania transnacional? 
A participaçăo na democracia do Estado é condiçăo essencial para que o transnacional possa ser considerado cidadăo? Afinal, democracia é a "forma de exercício da funçâo governativa em que a vontade do povo decide, direta ou indiretamente, todas as questóes de governo, de tal sorte que o povo seja sempre o titular e o objeto - a saber, o sujeito ativo e passivo de todo o poder legítimo" (BONAVIDES, 2004, p.17).

Segundo Carvalho (2008, p. 9-10), os direitos políticos dizem respeito à participaçâo do cidadăo no governo da sociedade, porém, "seu exercício é limitado a parcela da populaçăo e consiste na capacidade de fazer demonstraçôes políticas, de organizar partidos, de votar, de ser votado", sendo que, "em geral, quando se fala de direitos políticos, é do direito do voto que se está falando". O autor ainda acrescenta que os direitos políticos têm como "instituiçăo principal os partidos e um parlamento livre e representativo. Sâo eles que conferem legitimidade à organizaçăo política da sociedade. Sua essência é a ideia de autogoverno".

A titularidade de direitos políticos em regra é restrita aos nacionais de um Estado, portanto, ser cidadâo é ter direitos políticos, logo, o transnacional nâo poderia ser considerado como um cidadăo. No Brasil, por exemplo, a Constituiçăo Federal impede o estrangeiro de alistar-se como eleitor ( $\left(2^{\circ}\right.$, Art. 14) e impóe como condiçâo de elegibilidade a nacionalidade brasileira (inciso I, $\S 3^{\circ}$, Art. 14).

Até pouco tempo, eram vedadas ao estrangeiro a participaçăo em atividades políticas no território brasileiro, devido à Lei n. ${ }^{\circ}$ 6.815/1980, conhecida como Estatuto do Estrangeiro. Com a nova Lei de Migraçăo (Lei n. ${ }^{\circ}$ 13.445/2017), estas proibiçóes foram extintas.

O Brasil é o único país da América do Sul que năo garante o voto ao estrangeiro em alguma esfera: municipal, estadual ou federal. As Constituiçóes do Chile, Venezuela, Paraguai, Uruguai, Argentina, Bolívia, Colômbia, Equador e Peru possuem artigos que autorizam o voto do estrangeiro em alguma das três esferas de poder. Todas estas Magnas Cartas autorizam o voto do estrangeiro nas eleiçôes municipais, contudo, a maioria ainda restringe o voto nas eleiçōes nacionais.

Liszt Vieira escreve sobre uma "democracia cosmopolita":

A perspectiva da democracia cosmopolita propóe, assim, que a cidadania seja desvinculada do Estado soberano e investida em novas estruturas de cooperaçăo internacional. $\mathrm{O}$ problema náo é reconstituir o poder soberano em um domínio territorial mais amplo, mas promover múltiplos lugares de responsabilidade política representando fidelidades subestatais e transnacionais, além de nacionais. Os cidadăos poderiam assim exercer direitos políticos e expressar diferentes lealdades políticas em diversas esferas públicas (VIEIRA, 199, s/n).

Conferir cidadania apenas àqueles titulares dos direitos civis, políticos e sociais ao mesmo tempo, ou seja, aos "cidadâos plenos", nâo corresponde com a realidade da comunidade internacional globalizada da atualidade.

O arcabouço jurídico internacional e regional dos direitos humanos garante a proteçấo da dignidade da pessoa humana, ou seja, o ser humano como centro de toda esta normatividade. Com base nestas normas, o conceito clássico de cidadania foi ampliado, năo se restringido apenas à questăo dos direitos políticos, como será apresentado mais profundamente no item seguinte. 
Desta feita, a garantia dos direitos políticos complementaria a cidadania do transnacional quando este se encontra em um território estrangeiro, dando-lhe o direito de participaçăo direta no governo local. Entretanto, a năo titularidade dos direitos políticos nâo inviabilizaria a condiçăo de cidadăo transnacional do indivíduo. Explica-se.

A partir do momento em que o indivíduo transnacional adentra no território de um Estado, este já se vê compelido a tomar atitudes para garantir a dignidade deste indivíduo com base nos preceitos internacionais, regionais e nacionais dos direitos humanos. Assim, de certa forma, o transnacional influencia politicamente no governo do local onde se encontram, afinal, os governantes passam a movimentar a máquina estatal para que, pelo menos, os direitos civis e sociais sejam concedidos ao estrangeiro, como explica Sayad (1998) ao falar da definiçăo da imigraçăo e dos imigrantes, uma vez que é a soma do trabalho jurídico, afinal os direitos săo reconhecidos aos imigrantes; do trabalho político, pois há acordos entre as naçôes para definiçâo de forma de entrada, condiçóes de trabalho e etc.; por fim, do trabalho social, por meio de açóes diversas que visam a melhor adaptaçăo da populaçăo imigrante (SAYAD, 1998).

Ademais, há organizaçôes e instituiçōes que contribuem e atuam para que o transnacional possa ser integrado na sociedade como cidadăo. Esta atuaçăo perpassa pela esfera política tendo em vista a mobilizaçăo destas organizaçôes e instituiçóes junto aos governos locais, ou seja, mesmo que indiretamente, os transnacionais influenciam politicamente no governo local em que passam a residir. Afirma Sayad (1998) que os imigrantes sâo necessários para e economia do país que os recebe, portanto, sâo necessários, principalmente, para măo-de-obra e para resolver problemas demográficos, como a história brasileira confirma.

Portanto, nesta linha de pensamento, os direitos humanos se sobrepóem aos direitos políticos, uma vez que a mobilizaçāo do governo local é feita com base na dignidade da pessoa humana e em todo o arcabouço jurídico internacional, regional e nacional de proteçăo do indivíduo como ser humano. O voto ficaria em segundo plano.

Além dos direitos civis, políticos e sociais, podem-se ainda acrescentar os direitos econômicos e culturais nas categorias de direitos possíveis sobre os quais um cidadăo pode ter a titularidade, contribuindo na plenitude de sua cidadania.

Portanto, como pôde ser observado, para que seja considerado verdadeiramente como um "cidadăo pleno", o indivíduo deveria ter a titularidade das cinco categorias de direito aqui apresentadas. Porém, devido a circunstâncias normativas internas dos Estados, algumas destas categorias ainda săo concedidas aos transnacionais de modo integral ou parcialmente.

Todavia, a interpretaçăo da questâo da cidadania transnacional deve ir além das restriçôes normativas internas e dos conceitos restritivos clássicos da cidadania para uma interpretaçâo baseada no arcabouço jurídico internacional e regional de proteçâo dos direitos humanos, ou seja, uma interpretaçâo sob a ótica da dignidade da pessoa humana.

\section{CIDADANIA: ALÉM DA NACIONALIDADE}

Cidadania e nacionalidade, apesar de terem pontos de ligaçấo em seus conceitos clássicos, e apesar de o conceito restrito da cidadania, amplamente difundido, ter o 
caráter de vinculaçăo a um Estado, "com as mudanças sociais e a crescente transnacionalizaçăo - que é característica de uma sociedade globalizada - a cidadania passa a ser encarada com características mais vastas" (BACEGA DE BASTIANI; PELLENZ, 2015, p. 244).

Liszt Vieira expóe que o Estado-naçăo pode deixar de ser o lar da cidadania devido ao enfraquecimento da vinculaçấo até entâo existente entre os dois, uma vez que "o Estado năo tem mais o monopólio das normas, pois há regras internacionais que ele deve partilhar com a comunidade internacional. E perde força com o avanço da globalizaçăo" (VIEIRA, 1999, s/n).

Por sua vez, a cidadania tem seu significado além da expressăo "o direito a ter direitos", já que além de direitos, os cidadāos possuem deveres. Exercer a cidadania leva à responsabilidade, "participaçăo efetiva, consciência de voto, cumprimento das disposiçôes legais, controle da atividade governamental, interesse pelos rumos sociais e exercício da Democracia" (BACEGA DE BASTIANI; PELLENZ, 2015, p. 244).

Daniela Cademartori apresenta sua conclusăo sobre a definiçáo da cidadania ao longo da história:

Cidadania năo é uma definiçăo estanque, mas um conceito histórico, o que significa que seu sentido varia no tempo e no espaço. 0 que muda, de um Estado-naçáo para outro, năo săo só as regras que definem quem é ou năo cidadăo (ius soli ou ius sanguinis); também săo distintos os direitos e deveres, que caracterizam o cidadăo em cada um deles. Em cada um desses espaços territoriais, sociais e políticos, ao longo do tempo, o conceito de cidadania tem se alterado, seja incorporando ou náo os imigrantes, seja no que se refere ao grau de participaçáo dos diferentes grupos, seja no tocante à proteçăo propiciada pelo Estado aos que dela necessitam (CADEMARTORI, 2011, p.169).

Assim, a "lealdade a um Estado e a identificaçăo com uma naçăo" năo surgem apenas com os critérios do jus solis e do jus sanguinis, pois elas podem surgir de circunstâncias que levam o indivíduo a cruzar fronteiras, a buscar um novo território para viver e recomeçar a construçâo de sua cidadania. A recomeçar a se sentir cidadâo.

No contexto atual da transnacionalidade, povo e populaçăo se confundem e năo há como se conceber um Estado no qual o seu povo e sua populaçăo sejam integralmente homogêneos. Os deslocamentos humanos ao redor do mundo fizeram com que esta heterogeneidade popular fosse configurada.

Cruz e Bodnar (2011, p.60) afirmam que "o conceito de naçăo como grupo homogêneo, definido por características socioculturais ou religiosas comuns nâo se conjuga facilmente com a realidade dos atuais", sendo que um dos motivos para isso sâo os movimentos migratórios, os quais "foram e continuam sendo os grandes responsáveis pela eliminaçâo da homogeneidade cultural".

Assim, apesar de a Declaraçâo Universal dos Direitos Humanos prever o direito do indivíduo a emigrar e a retornar ao seu país de origem, ainda é direito de cada Estado estabelecer quem pode adentrar ou permanecer em seu território e qual indivíduo pode ser considerado seu cidadâo. Pinsky (2013) escreve sobre as várias dimensôes de direito que a um cidadăo devem ser reconhecidas:

Ser cidadăo é ter direito à vida, à liberdade, à propriedade, à igualdade perante a lei: é, em resumo, ter direitos civis. É também participar no destino da sociedade, 
votar, ser votado, ter direitos políticos. Os direitos civis e políticos năo asseguram a democracia sem os direitos sociais, aqueles que garantem a participaçâo do indivíduo na riqueza coletiva: o direito à educaçăo, ao trabalho, ao salário justo, à saúde, a uma velhice tranquila. Exercer a cidadania plena é ter direitos civis, políticos e sociais (PINSKY, 2013, p.9).

A cidadania "certifica o grau de acesso objetivo ao reconhecimento e participaçăo política e social" (LOPES, 2009, p.180), contudo, é comum que se restrinja a ideia de cidadăo àquela pessoa que possui direitos políticos, o direito a votar e ser votado. Em geral, apesar de poderem ser acolhidos como residentes e terem acesso à parte dos direitos civis e sociais, os transnacionais sâo excluídos dos direitos políticos.

Todavia, năo conceber o transnacional como cidadâo, excluindo-o da cidadania nacional, é uma forma simplista de tratar um sujeito de direitos humanos, alijando este indivíduo de uma integraçấo plena na sociedade onde se encontra. A cidadania proporciona o acesso a inúmeros direitos e deveres, além da igualdade entre nacionais e estrangeiros residentes.

Relacionar de modo objetivo os direitos humanos à cidadania é um imenso retrocesso. A universalidade dos direitos humanos năo pode ser direcionada apenas àquele considerado cidadăo nacional, bem como os direitos civis, sociais, políticos, econômicos e culturais plenos náo devem ser concedidos apenas ao cidadăo estatal.

A tradicional concepçăo da ligaçăo vertical entre Estado e cidadăo, resultado de critérios geográficos ou sanguíneos relacionados ao nascimento, perde força na contemporaneidade. A cidadania já năo se pressupóe irrestritamente à nacionalidade. Cademartori completa seu argumento ao afirmar que "nas sociedades complexas e plurais de nosso tempo, cujos Estados estâo inseridos em um contexto de multiculturalidade, multinacionalidade e até mesmo de transnacionalidade, é necessário revisar a equaçăo cidadăo-nacional" (CADEMARTORI, 2011, p.158).

A cidadania transnacional ganha espaço devido aos fluxos dos deslocamentos transnacionais, às relaçôes dos transnacionais com seu local de origem e de destino e, principalmente, com a internacionalizaçâo cada vez mais integral e organizada dos direitos humanos, os quais têm o objetivo de que a qualquer indivíduo, onde quer que eles se encontrem, possam ser garantidos direitos básicos.

O arcabouço jurídico internacional e regional de proteçâo dos direitos humanos, atrelados com a elevaçăo do indivíduo como sujeito de direitos humanos, além de todas as possibilidades atuais de existência do Estado Constitucional Cooperativo, contribuem com a atualizaçăo do conceito da cidadania.

A cidadania transpassou os limites territoriais do Estado graças aos inúmeros pactos internacionais, principalmente relacionados aos direitos humanos. A perspectiva verticalizada do vínculo Estado - cidadâo passou para a forma horizontalizada, na qual se caracteriza pela possibilidade de o indivíduo relacionar-se com o meio em que vive, passando a ter direitos e deveres.

Há uma dissociaçăo entre nacionalidade e cidadania, o que, segundo Liszt Vieira, "confere a esta última uma dimensâo puramente jurídica e política, afastando-a da dimensâo cultural existente em cada naçáo". Neste entendimento, "a cidadania passaria a ter uma proteçăo transnacional, como os direitos humanos. Por esta concepçâo, seria 
possível pertencer a uma comunidade política e nela ter participaçăo, independentemente de ser ou năo nacional" (VIEIRA, 1999, s/n).

Por isso, o conceito de cidadania pode (e deve) ser ampliado conforme os acontecimentos históricos dentro de um processo civilizatório que, atrelado aos direitos humanos, faz com que restriçōes devam ser repudiadas.

A cidadania necessita ser interpretada como um meio de se integrar socialmente àqueles que estăo nos processos migratórios e nâo mais restringir-se aos direitos formais limitados a um Estado. Ao garantir a cidadania, consequentemente garantem-se os direitos humanos de uma forma mais ampla, eficaz e institucionalizada (o Estado garante năo por obrigaçăo ou caridade, mas por legalidade).

\subsection{CIDADANIA TRANSNACIONAL}

Écada vez mais comum que blocos internacionais ou regionais, os quais se formaram inicialmente por questóes econômicas, passem a criar pactos relacionados aos cidadâos de seus Estados-membros, no intuito de garantirem a igualdade de direitos, livre circulaçấo e facilidade de residência. Da mesma maneira, poderá haver pactos bilaterais entre países fronteiriços no sentido de facilitar ou garantir tais benefícios aos nacionais dos Estados pactuantes.

Também é recorrente que países façam adequaçōes em suas legislaçôes internas relacionadas à migraçăo com o objetivo de manter uma coerência com os pactos internacionais de direitos humanos que já tenham sido ratificados por seus governos.

Como exemplos destas situaçóes podem ser citados: o Mercosul, que possui um plano de açâo para a implementaçăo de um Estatuto da Cidadania até 2021, visando beneficiar os cidadăos dos Estados-membros; o acordo de livre circulaçăo e residência permanente entre Brasil e Uruguai; e a sançăo, em maio de 2017, da nova lei de migraçăo brasileira (Lei n. ${ }^{\circ}$ 13.445, de 24 de maio de 2017), a qual descriminaliza a migraçăo e volta-se ao acolhimento do năo nacional. Iremos expor nesse artigo somente o Estatuto da Cidadania (Mercosul).

Sâo exemplos como estes que demonstram ser possível a concepçâo de uma cidadania transnacional na comunidade internacional contemporânea.

\section{MERCOSUL: PROJETO DE CIDADANIA TRANSNACIONAL}

Em 16 de dezembro de 2010, na cidade de Foz do Iguaçu, Paraná, sob a presidência do Brasil, os membros do Conselho do Mercado Comum se reuniram e assinaram a Decisâo CMC n. ${ }^{\circ}$ 64/2010, que criou um plano de açăo para que, até 2021, aniversário de 30 anos do bloco, seja implementado o Estatuto da Cidadania do Mercosul. O plano de açăo é uma "conformaçăo progressiva" deste Estatuto (art. 1º).

Para a criaçăo deste plano, foram apresentadas justificativas baseadas nas questôes de cidadania, integraçăo regional e igualdade de direitos dos cidadăos dos Estados Partes do Mercosul. O Conselho do Mercado Comum considerou fundamental, após vinte anos da assinatura do Tratado de Assunçăo, avançar "no aprofundamento da 
dimensáo social e cidadă do processo de integraçăo, com vistas a alcançar um desenvolvimento sustentável, com justiça e inclusăo social em benefício dos nacionais dos Estados Partes do Mercosul".

Contudo, ressaltou que "os instrumentos adotados no Mercosul garantem aos nacionais dos Estados Partes e as suas famílias o gozo dos mesmos direitos e liberdades civis, sociais, culturais e econômicas, de acordo com as leis que regulamentam o seu exercício", destacando que é necessária a consolidaçăo de um "conjunto de direitos fundamentais e benefícios em favor dos nacionais dos Estados Partes do Mercosul".

O Estatuto da Cidadania do Mercosul se conformará com base em três objetivos, apresentados no art. $2^{\circ}$ do plano de açăo: implementaçăo de uma política de livre circulaçâo de pessoas na regiấo; igualdade de direitos e liberdades civis, sociais, culturais e econômicas para os nacionais dos Estados Partes do Mercosul; igualdade de condiçóes para acesso ao trabalho, saúde e educaçáo. Estes objetivos, segundo a Decisâo CMC n. ${ }^{\circ}$ 64/2010, serấo "oportunamente elencados nos Tratados Fundamentais do Mercosul e na normativa derivada".

0 art. $3^{\circ}$ da Decisâo apresenta 11 (onze) elementos integrantes do plano de açăo, para que os objetivos indicados no art. $2^{\circ}$ possam ser alcançados. Os elementos săo: 1) Circulaçăo de pessoas; 2) Fronteiras; 3) Identificaçăo; 4) Documentaçăo e cooperaçâo consular; 5) Trabalho e emprego; 6) Previdência social; 7) Educaçấo; 8) Transporte; 9) Comunicaçōes; 10) Defesa do consumidor; e 11) Direitos políticos.

Todos estes elementos integrantes contribuem para a consolidaçâo de uma cidadania transnacional na esfera do Mercosul, contudo, é possível ressaltar os principais elementos contribuintes.

No primeiro elemento, "Circulaçáo de pessoas": "1.1 Facilitaçâo do trânsito e da circulaçăo no espaço Mercosul" e "1.2 Simplificaçăo de trâmites, agilizaçăo de procedimentos de controle migratório, harmonizaçăo gradual dos documentos aduaneiros e migratórios".

No terceiro elemento, "Identificaçăo": "3.1 Harmonizaçâo das informaçôes para a emissâo de documentos de identificaçăo nos Estados Partes do Mercosul" e "3.2 Inserçăo da denominaçấo "Mercosul" nas cédulas de identidade nacionais".

No quinto elemento, "Trabalho e emprego": "5.7 Desenvolvimento de plano regional em matéria de facilitaçăo da circulaçấo de trabalhadores".

No sexto elemento, "Previdência social": "6.1 Integraçăo dos cadastros de informaçóes previdenciárias e trabalhistas dos Estados Partes para fins de simplificaçâo de trâmites, segurança das informaçôes, formulaçăo de políticas públicas e agilizaçăo de concessâo de benefícios" e "6.2 Estabelecimento de um Programa de Educaçáo Previdenciária do Mercosul, que incluiria a criaçâo de um portal na Internet para facilitar o acesso a informaçōes previdenciárias".

No sétimo elemento, "Educaçăo": "7.1 Simplificaçăo dos trâmites administrativos para efeitos da equivalência de estudos e títulos de ensino superior"; "7.2 Aprofundamento do Sistema ARCU-SUL para a equivalência plena de cursos superiores no Mercosul"; e "7.3 Criaçấo de um Acordo-Quadro de Mobilidade para a consolidaçấo de um espaço de mobilidade (estudantes, professores e pesquisadores) e intercâmbios acadêmicos". 
No décimo elemento, "Defesa do consumidor": "10.1 Criaçăo de um Sistema Mercosul de Defesa do Consumidor".

Por fim, no décimo primeiro elemento, "Direitos políticos":

11.1 Avaliar as condiçôes para avançar progressivamente no estabelecimento de direitos políticos, de acordo com as legislaçôes nacionais que regulamentem seu exercício, em favor dos cidadăos de um dos Estados Partes do Mercosul que residam em outro Estado Parte de que năo sejam nacionais, incluindo a possibilidade de eleger parlamentares do Mercosul (MERCOSUL, 2010c, s.n).

Todos os onze elementos integrantes serâo discutidos em diferentes âmbitos, como, por exemplo, reuniôes de Ministros da Justiça, Ministros do Interior, Ministros da Educaçăo, no Grupo Mercado Comum, em Foro Especializado Migratório, etc. Estes âmbitos farâo recomendaçôes que, poderâo subsidiar o Conselho do Mercado Comum a atualizar e/ou ampliar o plano de açăo do Estatuto da Cidadania do Mercosul.

0 art. $6^{\circ}$ determina que estes foros do Mercosul deverăo elaborar um cronograma de trabalho de até 10 (dez) anos, para que haja a implementaçăo progressiva dos elementos que integram o plano de açăo, levando-se em conta os três objetivos apresentados no art. $2^{\circ}$.

Merece evidência o art. $7^{\circ}$ da Decisăo CMC n. ${ }^{\circ}$ 64/2010, o qual escreve: “O Estatuto da Cidadania do Mercosul poderá ser instrumentalizado por meio da assinatura de um protocolo internacional que incorpore o conceito de "Cidadâo do Mercosul" e forme parte do Tratado de Assunçăo".

Como se depreende da leitura do dispositivo está prevista a possibilidade de incorporaçăo no Estatuto da Cidadania e no Tratado de Assunçấo o conceito de "Cidadâo do Mercosul", fato que certamente vai ao encontro do exposto neste trabalho até o momento: a cidadania transnacional é uma realidade cada vez mais presente no contexto global, năo mais se concebendo a verticalizaçăo do conceito de cidadania (Estado - cidadâo).

Por se tratar de regulamentaçâo de aspectos da organizaçăo e funcionamento do Mercosul, a Decisăo CMC n. ${ }^{\circ}$ 64/2010 náo precisa ser incorporada ao ordenamento jurídico dos Estados Partes.

Importante dizer que os trabalhos referentes ao plano de açâo para a implementaçáo do Estatuto da Cidadania do Mercosul sâo coordenados pelo Alto RepresentanteGeral do Mercosul. Este órgăo foi criado no mesmo dia do plano açăo, por meio da assinatura da Decisâo CMC n. ${ }^{\circ}$ 63/2010.

Conforme o art. $2^{\circ}$ desta Decisăo, o Alto Representante-Geral "será uma personalidade política destacada, nacional de um dos Estados Partes, com reconhecida experiência em temas de integraçăo". Designado pelo Conselho do Mercado Comum, o Alto Representante-Geral terá mandato de três anos, podendo ser prorrogado por igual período pelo Conselho.

Diferentemente da Decisâo CMC n. ${ }^{\circ}$ 64/2010, a Decisâo CMC n. ${ }^{\circ}$ 63/2010 necessita de incorporaçấo ao ordenamento jurídico dos Estados Partes, sendo determinado pelo art. 21 que esta incorporaçăo ocorresse antes de 31 de dezembro de 2011.

Até que o Estatuto da Cidadania nâo seja implantado, a Comissâo de Representantes 
Permanentes do Mercosul, órgáo que assiste o Conselho do Mercado Comum e o Grupo do Mercado Comum, elaborou a Cartilha da Cidadania do Mercosul, com o intuito de compilar as principais normas vigentes no bloco que interessam aos cidadáos.

Disponível em português e espanhol, a cartilha é dividida em doze eixos temáticos: Circulaçấo de Pessoas e Bens; Trabalho e Previdência Social; Educaçăo; Defesa do Consumidor; Apoio à Produçăo e ao Comércio; Correspondência e Encomendas; Cooperaçâo Consular e Judicial; Direitos Humanos; Integraçâo Cultural; Aspectos Sanitários e de Saúde; Dimensáo Social e Temas Diversos. Em cada um destes eixos, săo destacados os órgâos dos Estados Partes e dos Estados Associados responsáveis por sua aplicaçâo.

Além das normas, é possível encontrar na Cartilha da Cidadania do Mercosul declaraçóes dos presidentes dos Estados Partes e recomendaçóes do Conselho do Mercado Comum, as quais "estabelecem, entre outros, as diretrizes políticas que devem orientar os órgáos do Mercosul e aos Estados Partes na sua relaçăo com a cidadania" (MERCOSUL, 2010b, s.n).

O Mercosul caminha para a concretizaçăo do conceito do "Cidadâo do Mercosul", mesmo sendo composto por cinco Estados Partes - Brasil, Argentina, Paraguai, Uruguai e Venezuela (a Bolívia ainda está em processo de adesăo) -, além de seis estados associados - Chile, Colômbia, Equador, Guiana, Peru e Suriname. O indivíduo seria considerado cidadâo em todo o bloco, além das fronteiras de seu país de origem.

Isto é a cidadania transnacional. Mesmo que a cidadania transnacional aqui defendida seja baseada nos preceitos dos direitos humanos, a cidadania transnacional do Mercosul acaba sendo derivada destes mesmos preceitos, afinal, os países do bloco também fazem parte de acordos e tratados internacionais de direitos humanos.

O próprio Mercosul possui o Protocolo de Assunçăo sobre Compromisso com a Promoçấo e a Proteçăo dos Direitos Humanos do Mercosul, assinado em Assunçáo, em 20 de junho de 2005 (promulgado no Brasil pelo Decreto n. ${ }^{\circ} 7.225$, de $1^{\circ}$ de julho de 2010). Conforme o artigo 1, este Protocolo visa estabelecer "a plena vigência das instituiçôes democráticas e o respeito dos direitos humanos e das liberdades fundamentais", os quais "săo condiçôes essenciais para a vigência e evoluçăo do processo de integraçăo entre as Partes".

Na parte inicial deste Protocolo, Argentina, Brasil, Paraguai e Uruguai reafirmam “os princípios e normas contidos na Declaraçăo Americana de Direitos e deveres do Homem, na Convençăo Americana sobre Direitos Humanos e outros instrumentos regionais de direitos humanos, assim como na Carta Democrática Interamericana"; e reconhecem "a universalidade, a indivisibilidade, a interdependência e inter-relaçâo de todos os direitos humanos, sejam direitos econômicos, sociais, culturais, civis ou políticos".

Assim, o processo de integraçăo regional do Mercosul deve observar os preceitos dos direitos humanos e da cidadania como forma de se garantir direitos aos indivíduos nacionais dos Estados Partes, năo importando em qual dos territórios nacionais eles estejam. 


\section{CONSIDERAÇÕES FINAIS}

A concepçăo do Estado soberano absoluto já năo se encaixa na sistemática da comunidade internacional contemporânea. Atualmente, prevalece a necessidade da interaçấo, cooperaçâo e solidariedade entre os Estados como forma de se garantir uma proteçấo mais eficaz e consolidada dos direitos humanos e da manutençâo da paz mundial.

Os processos de globalizaçăo fizeram com que aumentasse a interdependência entre os Estados, porém encurtasse as fronteiras estatais por conta do desenvolvimento dos meios de transporte e comunicaçăo.

Os deslocamentos humanos internacionais também nâo săo os mesmos como há anos atrás. Houve um aumento no fluxo dos deslocamentos humanos além das fronteiras estatais que obrigou os Estados a olharem com maior preocupaçăo e capacidade de açăo para a problemática, no sentido de resolver a questăo dos indivíduos que adentrarem em seu território.

Integrar os transnacionais na sociedade local passou a ser um dos maiores desafios dos Estados, nāo só por conta de critérios sociais, mas também por critérios políticos, uma vez que é necessário fazer com que a sociedade olhe o indivíduo transnacional com fulcro na alteridade, ou seja, na aceitaçâo do "outro", no respeito à diversidade cultural.

O ser humano que se desloca internacionalmente passou a ter ligaçôes que perpassam as fronteiras, no contexto da transnacionalidade presente no mundo dos dias de hoje. Esta transnacionalidade năo vê fronteiras estatais. Enquanto a globalizaçâo remete à unicidade, a transnacionalidade diz respeito ao transpasse dos limites fronteiriços.

Satisfatório seria se todos os indivíduos pudessem ser detentores dos direitos civis, sociais, políticos, econômicos e culturais conjuntamente, de forma a ser considerado um cidadâo pleno, porém, é evidente que a titularidade de um direito náo garante o outro. Assim, a náo titularidade de uma dessas categorias apresentadas no trabalho nâo pode afastar a possibilidade de o indivíduo ser considerado cidadâo, afinal, as normas (internacionais, regionais e nacionais) de proteçăo dos direitos humanos săo superiores, devendo estas prevalecer na falta de uma das categorias.

Deste modo, diante do exemplo do Mercosul apresentado, é possível afirmar que a cidadania transnacional é uma possibilidade jurídica contemporânea, uma vez que há um arcabouço jurídico de proteçâo dos direitos humanos vigente e válido, seja um sistema internacional, regional, doméstico ou um microssistema. O pluralismo jurídico auxilia na aplicaçâo conjunta e harmônica destes sistemas protetivos, dando prioridade à norma mais favorável ao indivíduo.

Apesar de haver fortes exemplos e indícios para se afirmar que a cidadania transnacional existe no cenário da atualidade, ainda é cedo para dizer que ela irá se consolidar na comunidade internacional. Para isto, é importante que se fique atento na conjuntura internacional, regional e nacional de proteçăo dos direitos humanos, pois é cada dia maior a ameaça de governos autoritários e nacionalistas extremos, os quais preferem criminalizar a migraçâo (espontânea ou forçada) do que buscar meios de se criar uma política migratória de integraçâo, auxiliando, assim, na consolidaçâo da cidadania transnacional. 


\section{REFERÊNCIAS}

BACEGA DE BASTIANI, Ana Cristina; PELLENZ, Mayara. Cidadania Transnacional: a Integraçáo Jurídica na Sociedade Globalizada. Cadernos do Programa de Pós-Graduaçăo em Direito - PPGDir./UFRGS, Porto Alegre, v. 10, n. 2, out. 2015. Disponível em: <http:// seer.ufrgs.br/index.php/ppgdir/article/view/54413>. Acesso em: 17 jun. 2018.

BONAVIDES, Paulo. A constituiçăo aberta. Săo Paulo: Malheiros, 2004.

BRASIL. Constituiçấo (1988). Constituiçâo da República Federativa do Brasil. Diário Oficial da República Federativa do Brasil, Brasília, DF, 5 out. 1988. Disponível em: 〈http://www.planalto.gov.br/ccivil_03/constituicao/constituicaocompilado.htm>. Acesso em: 02 mai. 2018.

BRASIL. Lei n 6.815, de 19 de agosto de 1980. Define a situaçâo jurídica do estrangeiro no Brasil, cria o Conselho Nacional de Imigraçăo. Diário Oficial da República Federativa do Brasil, Brasília, DF, 21 ago. 1980. Disponível em: <http://www.planalto.gov.br/ CCIVIL_03/leis/L6815compilado.htm>. Acesso em: 29 out. 2018.

BRASIL. Lei. 13.445, de 24 de maio de 2017. Institui a Lei de Migraçăo. Disponível em: < http://www.planalto.gov.br/ccivil_03/_ato2015-2018/2017/lei/L13445.htm>. Acesso em: 10 dez. 2018.

BRASIL. Ministério da Justiça. Anteprojeto de Lei de Migraçôes e Promoçăo dos direitos dos migrantes no Brasil. 2013. Disponível em: <http://pt.slideshare.net/justicagovbr/ anteprojeto-novo-estatutoestrangeiro>.Acesso em: 13 jul. 2018.

CADEMARTORI, Daniela Mesquita Leutchuk de. Limites e possibilidades de uma cidadania transnacional: uma apreensăo histórico-conceitual. In: CRUZ, Paulo Márcio; STELZER, Joana. (Orgs.). Direito e Transnacionalidade. Curitiba: Juruá, 2011.

CARVALHO, Maximiliano Pereira de.; JUNQUEIRA, Fernanda Antunes Marques. O trabalho e o imigrante em situaçáo irregular: à espera de uma absolviçâo. Panóptica. Vitória, vol. 8, n. 1 (n.25), 2013. Disponível em: <http://www.panoptica.org/seer/index.php/op/ article/view/299/323>. Acesso em: 11 ago.2018

CRUZ, Paulo Márcio; BODNAR, Zenildo. A transnacionalidade e a emergência do Estado e do Direito transnacionais. In: CRUZ, Paulo Márcio; STELZER, Joana (Orgs.). Direito e Transnacionalidade. Curitiba: Juruá, 2011.

MARSHALL, T. H. Cidadania, Classe Social e Status. Rio de Janeiro: Zahar Editores, 1967.

MERCOSUL. Alto Representante-Geral do Mercosul. Foz do Iguaçu. 16 de Dezembro de 2010a. Disponível em: <http://dai-mre.serpro.gov.br/atos-internacionais/multilaterais/ decisao-cmc-no-63-10-alto-representante-geral-do-mercosul/at_download/arquivo.>. Acesso em: 28 jun. 2018. 
MERCOSUL. Cartilha da cidadania do Mercosul. Montevidéu, 2010b. Disponível em: <http://www.cartillaciudadania.mercosur.int/pt> Acesso em: 28 jun. 2018.

MERCOSUL. Estatuto da cidadania do Mercosul. Plano de Açáo. Foz do Iguaçu. 16 de Dezembro de 2010c. Disponível em: <http://www.mercosur.int/innovaportal/ file/2810/1/DEC_064-2010_PT_Estatuto_da_Cidadania.pdf.>. Acesso em: 01 mai. 2018.

PINSKY, Jaime. História da Cidadania. Pinsky, Jaime; Bassanezi Pinsky, Carla. (orgs.). 6.ed. Sáo Paulo: Contexto, 2013. Disponível em: <http://editoracontexto.com.br/historia-da-cidadania.html\#yt_tab_products1>Acesso em: 01 mai. 2018.

SANTOS, Milton. Por uma outra globalizaçăo - do pensamento único à consciência universal. Rio de Janeiro: Record, 2006. 85 p.

SAYAD, Abdelmalek. A imigraçăo ou os paradoxos da alteridade. Săo Paulo: Edusp, 1998. 299 p.

SILVEIRA, Vladmir Oliveira da; ROCASOLANO, Maria Mendez. Direitos Humanos: conceitos, significados e funçōes. Săo Paulo: Saraiva, 2010.

SOBRINHO, LitonLanesPilau; SIRIANNI, Guido; PIFFER, Carla. Migraçōes Transnacionais e Multiculturalismo: um desafio para a Uniâo Europeia. Novos Estudos Jurídicos, v. 19, n. 4, p. 1159-1184, 2014. Disponível em: <http://siaiap32.univali.br/seer/index.php/nej/ article/viewFile/6702/3823>. Acesso em: 20 abr. 2018.

TAVARES, André Ramos. Curso de Direito Constitucional. 6. ed. rev. e atual. Sāo Paulo: Saraiva, 2008.

VIEIRA, Liszt. Cidadania Global e Estado Nacional. Dados, Rio de Janeiro, v. 42, n. 3, p. 395-419, 1999. Disponível em: <http://www.scielo.br/scielo.php?script=sci_arttext\&pid=S0011-52581999000300001 >. Acesso em: 20 nov. 2018. 